\title{
Steroid Hormone Exposure as a Potential Hazard in Milk Consumers: A Significant Health Challenge in Iran
}

\author{
Amir Nili-Ahmadabadi $\left(\mathbb{D},{ }^{1,2}\right.$ Fatemeh Rezaei $\mathbb{D}^{1,2}$ Ali Heshmati ${ }^{10},^{3}$ \\ Akram Ranjbar $\mathbb{D}^{1,2}$ and Amir Larki-Harchegani $\mathbb{D}^{1,2}$ \\ ${ }^{1}$ Medicinal Plants and Natural Products Research Center, Hamadan University of Medical Sciences, Hamadan, Iran \\ ${ }^{2}$ Department of Pharmacology and Toxicology, School of Pharmacy, Hamadan University of Medical Sciences, Hamadan, Iran \\ ${ }^{3}$ Department of Nutrition and Food Safety, School of Medicine, Nutrition Health Research Center, \\ Hamadan University of Medical Sciences, Hamadan, Iran
}

Correspondence should be addressed to Amir Larki-Harchegani; dr.amir.larki@gmail.com

Received 17 February 2021; Revised 24 August 2021; Accepted 6 September 2021; Published 1 October 2021

Academic Editor: Yan Zhang

Copyright $\odot 2021$ Amir Nili-Ahmadabadi et al. This is an open access article distributed under the Creative Commons Attribution License, which permits unrestricted use, distribution, and reproduction in any medium, provided the original work is properly cited.

\begin{abstract}
The presence of steroid hormones in milk is inevitable, and they can be considered as potential carcinogenic agents for consumers. The purpose of this study was to evaluate the level of $17 \beta$-estradiol, progesterone, and hydroxyprogesterone in sixty-nine bovine milk samples, collected from April to September 2020, in Hamadan, Iran. The milk samples were analyzed using enzyme-linked immunosorbent assay (ELISA). In this study, the mean contents of $17 \beta$-estradiol, progesterone, and hydroxyprogesterone in the milk samples were determined to be $330.5 \pm 190.2 \mathrm{pg} / \mathrm{ml}, 3.57 \pm 2.47 \mathrm{ng} / \mathrm{ml}$, and $1.54 \pm 0.41 \mathrm{ng} / \mathrm{ml}$, respectively. However, the content of these steroid hormones in milk samples could be considered safe in children and adults, if the milk consumption is assumed to be in the reported range (175-240 ml/daily). Due to the effects of steroid hormones, especially $17 \beta$-estradiol, in the etiology of various cancers, regular monitoring of these hormones is recommended in milk and its dairy products in Iran.
\end{abstract}

\section{Introduction}

Milk is one of the most important sources of calcium and protein for the humans that plays the main role in the worldwide food pyramid $[1,2]$. Based on the 2017 report of the United Nations food and agriculture organization (FAO), milk consumption per capita in the world is approximately $100 \mathrm{~kg} /$ years, which may be very variable in various regions [3]. Meanwhile, milk consumption per capita in Iran is lower than the consumption in the world and estimated to be $66.12 \mathrm{~kg}$ per year. According to the FAO's report, the average milk production in Iran has increased remarkably from 4 million tons in 1998 to 8.8 million tons in 2014 [4].

This food source is prone to a variety of environmental contaminants such as mycotoxins [5], pesticides [6], heavy metals [7], melamine [8], antibiotics, and different hormones $[9,10]$. Among these, the presence of steroid hormones in milk and dairy products is inevitable and can be considered as a threatening factor in consumers $[10,11]$. The part of milk hormones originates naturally from internal glands and, subsequently, the blood flow and are secreted in milk via diffusion [12]. In addition, steroid hormones are used to increase milk production and improve reproductive performance in animal husbandry [13]. Therefore, it is expected that milk is considered a rich source of endogenous and exogenous steroid hormones, whose content in the milk often exceeds that in the maternal blood plasma. The level of these lipophilic compounds depends on the fat level of the milk [14]. Food processing, such as churning and/or heating, does not appear to influence the amount of the steroid hormones [15].

The presence of steroid hormones in milk can be one of the most effective factors in the occurrence of hormonal disorders and their consequences [16]. For instance, Maruyama et al. [17] showed that men who consumed at 
least $600 \mathrm{~mL} / \mathrm{m}^{2}$ of the body surface area of cow's milk had higher contents of steroid hormones including estradiol, estrone, and progesterone in urine and serum. These men had declined serum levels of testosterone and pituitary gonadotropins about hours after drinking the milk [17]. In international comparisons, daily consumption of milk and dairy products is strongly associated with rates of various cancers, especially prostate and ovarian cancers $[18,19]$. In addition, total milk and dairy consumption have been correlated with the occurrence of endometrial cancer, mostly among postmenopausal women who are not receiving hormone therapy, a finding probably associated to the steroid hormone content of dairy products [20].

Hamadan (the latitudes $33^{\circ} 33^{\prime}$ to $35^{\prime} 48^{\prime} \mathrm{N}$ and longitudes $47^{\circ} 45^{\prime}$ to $49^{\prime} 36^{\prime} \mathrm{E}$ ), a region in western Iranthat, due to its geographical location and climatic status, provides a considerable part of milk for different regions of Iran. According to the estimates made from animal husbandries, approximately $80 \%$ of the milk produced comes from pregnant cows, which naturally has significant levels of steroid hormones [17]. There are also unofficial reports on the use of steroid medicines to increase milk production in Iranian animal husbandry. Given that $60-80 \%$ of steroid hormones enter the body through the consumption of milk and dairy products [14], it is very important to determine the appropriate amount of consumption of these products to prevent carcinogenic and destructive effects of these hormones. Therefore, in order to evaluate the risk of these hormones through milk consumption in consumers, the levels of three steroid hormones in Hamadan milk samples were measured by the enzyme-linked immunosorbent assay (ELISA) method, and its result was compared to $\mathrm{FAO} / \mathrm{WHO}$ food standards.

\section{Materials and Methods}

2.1. Sampling. As shown in Figure 1, sixty-nine bovine milk samples (from four different zones) were randomly collected from Hamadan markets during the period of April to September 2020. All samples were kept at $-20^{\circ} \mathrm{C}$ and analyzed as soon as possible.

2.2. Sample Preparation and Hormone Analysis. The sample preparation was down according to the method of Yang et al. [21] with some modifications. Briefly, $1 \mathrm{~mL}$ of the sample was transferred into a microtube. Then, $200 \mu \mathrm{L}$ of acetate buffer (0.2 M, pH 5.2) was added and homogenized using a homogenizer for $1 \mathrm{~min}$. For deconjugation of steroid hormones, $20 \mu \mathrm{L}$ glucuronidase/arylsulfatase was added and incubated overnight at $37^{\circ} \mathrm{C}$. Then, $0.5 \mathrm{ml}$ of the sample was transferred into a microtube and $0.5 \mathrm{ml}$ of methanol was added to precipitate milk proteins. Following $3 \mathrm{~min}$ of vortex shaking, the samples were centrifuged (at $25^{\circ} \mathrm{C}$ for $10 \mathrm{~min} /$ $3500 \mathrm{~g}$ ) and their supernatant was separated and cleaned using solid-phase extractions (SPE). The quantitative analysis of steroid hormones was carried out using competitive enzyme-linked immunosorbent assay (ELISA) kits
(DiaMetra, Spello Perugia, Italy) according to the manufacturer's instructions.

2.3. Quality Assurance. Calibration curves for each steroid hormone were constructed using external standards, prepared by dilution of a stock solution in deionized water. Then, the limits of quantification were determined as $(\mathrm{SD} / \mathrm{S}) \times 10$, where $\mathrm{SD} / \mathrm{S}$ is the ratio of standard deviation/slope of the calibration curve [22]. Quality control samples were prepared by spiking milk samples with different concentrations of $17 \beta$-estradiol $(25,50$ and $500 \mathrm{pg} / \mathrm{ml}$ ), progesterone (5, 10 and $20 \mathrm{ng} / \mathrm{ml}$ ), and hydroxyprogesterone $(1.5,3$, and $6 \mathrm{ng} / \mathrm{ml})$ standards. Following $1 \mathrm{~min}$ of vortex shaking, samples were homogenized in an ultrasonic water bath for $30 \mathrm{~min}$. Finally, the ELISA technique was validated to ensure data quality using measurement of recoveries and the average variation coefficient for milk spiked with various concentrations of each hormone.

2.4. Health Risk Assessment. As shown in equation (1), the estimate daily intake (EDI) of steroid hormones was calculated using the average body weight of child and adult consumers $\left(W_{\mathrm{bw}}\right)$, the amount of milk consumed $\left(F_{\mathrm{M}}\right)$, and the level of steroid hormones in milk $\left(C_{\mathrm{SH}}\right)$.

$$
\operatorname{EDI}(\mathrm{ng} / \mathrm{kgbw} / \mathrm{day})=\frac{\mathrm{FM}(\mathrm{ml}) \times \mathrm{CSH}(\mathrm{ng} / \mathrm{ml})}{W_{b w}(\mathrm{~kg})} .
$$

According to the work of Abedi et al. [4], the average of milk consumption in children (4-10 years) and adults (18-50) in Iran was considered to be about 240 and $175 \mathrm{ml} /$ day, respectively. In addition, the body weight for the child and adult consumers is equal 70 and $26 \mathrm{~kg}$, respectively, based on the body weight studies by environmental protection agency $[4,23]$. In addition, the hazard quotient (HQ) index was calculated based on the following equation:

$$
\mathrm{HQ}=\frac{\mathrm{EDI}}{\mathrm{ADI}}
$$

\section{Results and Discussion}

The lactating race selection and improvement of the zootechnical situation in animal husbandry is ongoing, and therefore, the level of milk production per cow is much elevated [14]. This increase may be the outcome of alterations in the endocrinological system of the lactating cow which can affect the profile of steroid hormones in milk as a cancer risk factor [24]. Hence, the growing consumption of milk and dairy products has become a serious health challenge in recent years [25].

In the current study, the content of steroid hormone in milk samples from different regions of Hamadan was measured after validation of the ELISA procedure. As shown in Table 1, the $r^{2}$ indexes indicated an acceptable standard curve in the defined ranges. In addition, the results of recovery experiments and their relative standard deviation 


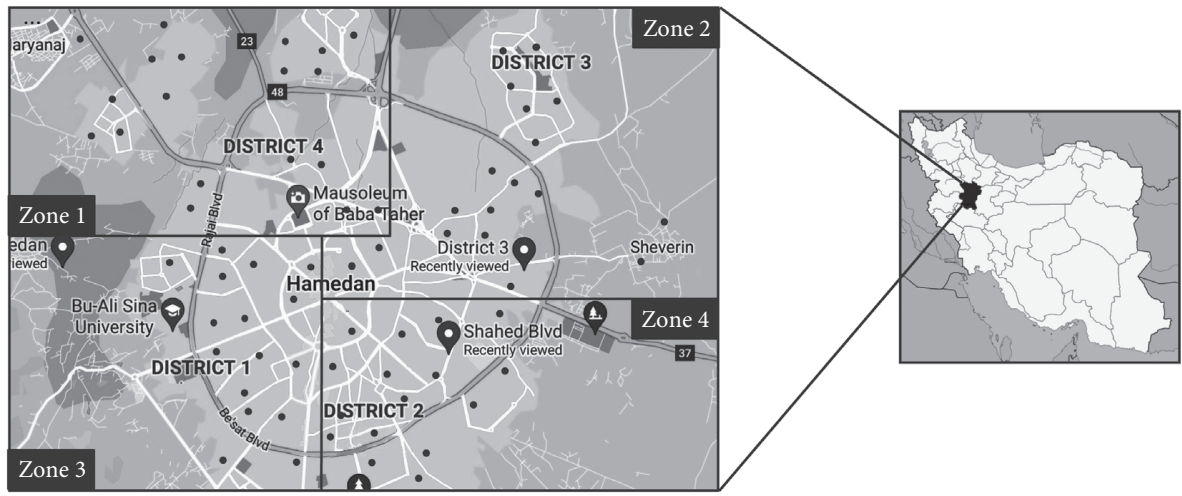

FIgURE 1: Geographical locations of milk sampling sites in Hamadan city, Iran.

TABLE 1: Linearity range and quantification limits for steroid hormones analyses using the ELISA method.

\begin{tabular}{lcccc}
\hline Steroid hormones & Range & Linear equation $^{\dagger}$ & $r^{2}$ & Limit of quantification $^{2}$ \\
\hline $17 \beta$-Estradiol $(\mathrm{pg} / \mathrm{ml})$ & $20-2000 \mathrm{pg} / \mathrm{ml}$ & $Y=-4.0453 X^{2}+0.6277 X+3.2752$ & 0.9948 & $8.68 \mathrm{pg} / \mathrm{ml}$ \\
Progesterone $(\mathrm{ng} / \mathrm{ml})$ & $0.2-40 \mathrm{ng} / \mathrm{ml}$ & $Y=-1.1442 X^{2}+0.0356 X+1.726$ & 0.9954 & $0.05 \mathrm{ng} / \mathrm{ml}$ \\
Hydroxyprogesterone $(\mathrm{ng} / \mathrm{ml})$ & $0.2-20 \mathrm{ng} / \mathrm{ml}$ & $Y=-0.0322 X^{2}-0.8332 X+1.4682$ & 0.9892 & $0.05 \mathrm{ng} / \mathrm{ml}$ \\
\hline
\end{tabular}

${ }^{\dagger}$ The absorbance changes (at $450 \mathrm{~nm}$ ) were plotted relative to the logarithmic concentrations of each hormone.

(RSD) values were within the acceptable ranges, showing good precision and accuracy of these analytical methods (Table 2).

The identification of steroid hormones in milk that have the potential to reproductive dysfunction has raised concern [10]. 17 $\beta$-Estradiol is the main estrogen secreted by the premenopausal ovary. It is synthesized from testosterone primarily in the ovarian granulosa cells and placenta, but small levels can be produced in the adrenal gland [26]. In dairy cows, pregnancy is related to the faster reduction in milk production [27]. 17 $\beta$-Estradiol can stimulate the growth of tumors and is associated with the occurrence of breast cancer [28]. In this study, 17 $\beta$-estradiol was detected in all of the milk samples in the range $75.6-922.3 \mathrm{ng} / \mathrm{L}$ and its mean contamination level was determined as $330.5 \pm 190.2 \mathrm{ng} / \mathrm{L}$ (Table 3). Several studies have reported $17 \beta$-estradiol levels in milk samples. For instance, Malkinejadet al. [14] reported $17 \beta$-estradiol levels in processed milk and raw milk at the range of 5.6 to $51 \mathrm{ng} / \mathrm{L}$. Chen et al. [29] detected the level of the $17 \beta$ estradiol in commercial milk samples in the range of 0 to $70.12 \mathrm{ng} / \mathrm{L}$. An important part of produced milk is obtained from pregnant cows; therefore, the content of the milk steroids depends on the different stages of the pregnancy. During pregnancy, the secretion of steroid hormones such as estrogens and progesterone increases [27]. Based on previous reports, the cumulative concentration of estrogens in the third trimester is about 27 times higher than that in the milk of cows in their first trimester of pregnancy [14]. In this regard, Japanese investigators have displayed that milk samples from a cow in the late stage of pregnancy contain up to 33 times as much estrone sulfate than milk from a nonpregnant cow [30]. Their findings could at least partially explain the high standard deviation in our data.
Progesterone is a steroid hormone generated by the cow during ovulation and could be assayed within milk samples [31]. This hormone rises and falls during various stages of the cow's reproductive cycle [32]. In the current study, progesterone was determined in all of the milk samples in the range of 0.69 to $12.1 \mathrm{ng} / \mathrm{ml}$ and its mean contamination level was detected $3.57 \pm 2.47 \mathrm{ng} / \mathrm{ml}$ (Table 4). Previously, Ginther et al. [33] exhibited the range of milk progesterone contents between 15.1 and $26.2 \mu \mathrm{g} / \mathrm{L}$ during pregnancy [33]. In addition, Regal et al. [34] showed that the average contents of progesterone were 0.824 and $0.082 \mu \mathrm{g} / \mathrm{L}$ in raw milk from pregnant and nonpregnant cows, respectively [34]. In addition, in the study of Wu et al. [35], the average of progesterone level were reported about $0.5 \mathrm{ng} / \mathrm{ml}$ and $4.48 \mathrm{ng} / \mathrm{ml}$ in milk samples of nonpregnant and pregnant cows, respectively [35]. It seems that the stage of the pregnancy or estrous cycle can have a predominant role on milk progesterone level [36]. In this regard, there is an obvious relation between milk output and double ovulation, and it is now confirmed that this phenomenon could be related to the circulating progesterone levels near the time of follicle selection [37].

Hydroxyprogesterone is a biological progestin that is generated following steroid hormone synthesis and is raised during early pregnancy [38]. In this study, hydroxyprogesterone was measured in all of the milk samples in the range of 0.80 to $2.61 \mathrm{ng} / \mathrm{ml}$ and its average contamination level was detected as $1.54 \pm 0.41 \mathrm{ng} / \mathrm{ml}$ (Table 5). There is no evidence about the hazardous of hydroxyprogesterone in milk, but due to the role of this hormone in increasing the expression of progesterone receptors, a permissible limit should be considered for it.

In this study, the $17 \beta$-estradiol and progesterone daily intake in both age groups of children and adults was estimated in the Iranian population. The Joint FAO/WHO Expert Committee on Food Additives has reported an ADI 
TABLE 2: Recoveries of steroid hormones in spiked milk samples.

\begin{tabular}{|c|c|c|c|c|c|}
\hline Hormones & Hormone spiked & Hormone sample & Hormone found & Recovery (\%) & $\operatorname{RSD}(\%)^{\dagger}$ \\
\hline \multirow{3}{*}{$17 \beta$-Estradiol $(\mathrm{pg} / \mathrm{ml})$} & 25 & 198 & 197 & 88.3 & 5.4 \\
\hline & 50 & 198 & 413 & 92.1 & 4.4 \\
\hline & 500 & 198 & 659 & 94.4 & 4.8 \\
\hline \multirow{3}{*}{ Progesterone (ng/ml) } & 5 & 4.4 & 8.9 & 94.6 & 6.1 \\
\hline & 10 & 4.4 & 14.1 & 97.9 & 5.5 \\
\hline & 20 & 4.4 & 21.1 & 86.4 & 5.8 \\
\hline \multirow{3}{*}{ Hydroxyprogesterone (ng/ml) } & 1.5 & 0.13 & 1.5 & 93.7 & 4.6 \\
\hline & 3 & 0.13 & 2.7 & 86.2 & 5.7 \\
\hline & 6 & 0.13 & 5.6 & 91.3 & 3.9 \\
\hline
\end{tabular}

${ }^{\dagger}$ Relative standard deviation (RSD) was obtained from triplicate tests.

Table 3: Milk 17 $\beta$-estradiol level and its daily intake in the different regions of Hamadan, Iran.

\begin{tabular}{|c|c|c|c|c|c|c|c|}
\hline \multirow{2}{*}{\multicolumn{4}{|c|}{$17-\beta$ Estradiol (ng/L) }} & \multicolumn{4}{|c|}{ Daily intake (ng/kg body weight) } \\
\hline & & & & \multicolumn{2}{|c|}{ Child } & \multicolumn{2}{|c|}{ Adult } \\
\hline Zones & $n$ & Mean \pm SD & Min-max & Mean \pm SD & Min-max & Mean \pm SD & Min-max \\
\hline Zone 1 & 19 & $318.0 \pm 199.8$ & $86.3-922.3$ & $2.93 \pm 1.84$ & $0.79-8.51$ & $0.79 \pm 0.49$ & $0.21-2.30$ \\
\hline Zone 2 & 18 & $288.0 \pm 182.5$ & $75.6-681.7$ & $2.65 \pm 1.68$ & $0.69-6.29$ & $0.72 \pm 0.45$ & $0.18-1.70$ \\
\hline Zone 3 & 16 & $443.4 \pm 184.7$ & $151.6-842.9$ & $4.09 \pm 1.70$ & $1.39-7.78$ & $1.10 \pm 0.46$ & $0.37-2.10$ \\
\hline Zone 4 & 16 & $282.2 \pm 133.0$ & $93.8-503.0$ & $2.60 \pm 1.22$ & $0.86-4.64$ & $0.70 \pm 0.33$ & $0.23-1.25$ \\
\hline
\end{tabular}

TABLE 4: Milk progesterone level and its daily intake in the different regions of Hamadan, Iran.

\begin{tabular}{lccccccc}
\hline & \multicolumn{2}{c}{ Progesterone $(\mathrm{ng} / \mathrm{ml})$} & & \multicolumn{3}{c}{ Daily intake (ng/kg body weight) } \\
Zones & $\mathrm{n}$ & Mean \pm SD & Min-max & Mean \pm SD & Min-max & Mean \pm SD & Min-max \\
\hline Zone 1 & 19 & $2.74 \pm 1.85$ & $1.26-7.81$ & $25.30 \pm 17.14$ & $11.67-72.13$ & $6.85 \pm 4.64$ \\
Zone 2 & 18 & $3.69 \pm 2.38$ & $0.69-7.43$ & $34.08 \pm 22.02$ & $6.45-68.62$ & $9.23 \pm 5.96$ & $1.74-18.58$ \\
Zone 3 & 16 & $4.77 \pm 3.12$ & $1.38-12.0$ & $44.04 \pm 28.81$ & $12.74-111.46$ & $11.92 \pm 7.80$ \\
Zone 4 & 16 & $3.10 \pm 1.83$ & $1.56-8.76$ & $28.63 \pm 16.90$ & $14.40-80.93$ & $7.75 \pm 4.57$ \\
\hline
\end{tabular}

TABLE 5: Milk hydroxyprogesterone level and its daily intake in the different regions of Hamadan, Iran.

\begin{tabular}{|c|c|c|c|c|c|c|c|}
\hline \multirow{2}{*}{\multicolumn{4}{|c|}{ Hydroxyprogesterone(ng/ml) }} & \multicolumn{4}{|c|}{ Daily intake (ng/kg body weight) } \\
\hline & & & & \multicolumn{2}{|c|}{ Child } & \multicolumn{2}{|c|}{ Adult } \\
\hline Zones & $\mathrm{n}$ & Mean \pm SD & Min-max & Mean \pm SD & Min-max & Mean \pm SD & Min-max \\
\hline Zone 1 & 19 & $1.48 \pm 0.46$ & $0.81-2.61$ & $13.71 \pm 4.30$ & $7.54-24.12$ & $3.71 \pm 1.16$ & $2.04-6.53$ \\
\hline Zone 2 & 18 & $1.45 \pm 0.45$ & $0.80-1.22$ & $13.45 \pm 4.23$ & $7.41-20.57$ & $3.64 \pm 1.14$ & $2.00-5.57$ \\
\hline Zone 3 & 16 & $1.72 \pm 0.30$ & $1.24-2.23$ & $15.92 \pm 2.78$ & $11.50-20.66$ & $4.31 \pm 0.75$ & $3.11-5.59$ \\
\hline Zone 4 & 16 & $1.52 \pm 0.33$ & $0.90-1.94$ & $14.11 \pm 3.11$ & $8.37-17.95$ & $3.82 \pm 0.84$ & $2.26-4.86$ \\
\hline
\end{tabular}

TABLE 6: Calculation of HQ index based on the average of daily intake of steroid hormones by milk consumption in Hamadan, Iran.

\begin{tabular}{|c|c|c|c|c|c|}
\hline \multirow{2}{*}{ Steroid hormones } & & \multicolumn{2}{|c|}{ Daily intake(ng/kg body weight) } & \multicolumn{2}{|c|}{ Hazard quotient (HQ) index ${ }^{\dagger}$} \\
\hline & & Mean \pm SD & Min-max & Mean \pm SD & Min-max \\
\hline \multirow{2}{*}{$17 \beta$-Estradiol } & Child & $3.05 \pm 1.75$ & $0.69-8.51$ & $0.06 \pm 0.035$ & $0.01-0.17$ \\
\hline & Adult & $0.82 \pm 0.47$ & $0.189-2.30$ & $0.016 \pm 0.009$ & $0.003-0.046$ \\
\hline \multirow{2}{*}{ Progesterone } & Child & $32.95 \pm 22.8$ & $6.36-111.69$ & $<0.001$ & $<0.001-0.003$ \\
\hline & Adult & $8.92 \pm 6.17$ & $1.72-30.25$ & $<0.001$ & $<0.001$ \\
\hline
\end{tabular}

${ }^{\dagger}$ If the HQ value is less than 1 , there is no risk through consumption of milk.

for $17 \beta$-estradiol and progesterone equal $50 \mathrm{ng} / \mathrm{kgbw}$ and $30 \mu \mathrm{g} / \mathrm{kgbw}$, respectively [39], whereas the estimated exposure was calculated via dividing the daily intake of these hormones by their safe limits. As presented in Table 6, the results of this research show that the $17 \beta$-estradiol and progesterone contents in milk samples could be considered 
safe in children and adults, if the milk consumption is assumed to be in the defined range (175-240 ml/daily).

If the maximum contents of steroid hormones are considered in exposure assessment estimates, consuming more than $1.5 \mathrm{~L} /$ day of milk could put children at high risk for $17 \beta$-estradiol. Although consuming this amount of milk per day seems unlikely, due to the high consumption of dairy products in Iran, there is a possibility of exposure to significant amounts of $17 \beta$-estradiol.

\section{Conclusions}

Taken collectively, due to the fact that many dairy products are made from cow's milk and estradiol has a high stability in it, the risks of $17 \beta$-estradiol exposure through the consumption of milk and dairy products might be worrisome for consumers. In contrast, the risk of progesterone exposure through milk consumption seems very small and even unlikely. However, attention should be given to regular monitoring of steroid hormones in milk and its dairy products, due to the rising trend of consuming these products among the Iranian population.

\section{Data Availability}

The data that support the findings of this study are available from the corresponding author upon reasonable request.

\section{Conflicts of Interest}

The authors declare no conflicts of interest.

\section{Acknowledgments}

This research was the M.Sc thesis of the second author that was supported by the vice-chancellor for research and technology, Hamadan University of Medical Sciences, Hamadan, Iran (Grant no. 9806124511).

\section{References}

[1] S. Singhal, R. D. Baker, and S. S. Baker, "A comparison of the nutritional value of cow's milk and nondairy beverages," Journal of Pediatric Gastroenterology \& Nutrition, vol. 64, no. 5, pp. 799-805, 2017.

[2] A. A. Hemmati, A. Larki-Harchegani, S. shabib, A. Jalali, and A. Rezaei, "Wound healing property of milk in full thickness wound model of rabbit," International Journal of Surgery, vol. 54, pp. 133-140, 2018.

[3] FAO, Gateway to Dairy Production and Products. Milk and Milk Products, FAO, Rome, Italy, 2017.

[4] A.-S. Abedi, E. Nasseri, F. Esfarjani, F. Mohammadi-Nasrabadi, M. H. Moosavi, and H. Hoseini, "A systematic review and meta-analysis of lead and cadmium concentrations in cow milk in Iran and human health risk assessment," Environmental Science and Pollution Research, vol. 27, pp. 1-13, 2020.

[5] T. A. Becker-Algeri, D. Castagnaro, K. de Bortoli, C. de Souza, D. A. Drunkler, and E. Badiale-Furlong, "Mycotoxins in bovine milk and dairy products: a review," Journal of Food Science, vol. 81, pp. R544-R552, 2016.
[6] S. Akhtar and K. Ahad, "Pesticides residue in milk and milk products: mini review," Pakistan Journal of Analytical \& Environmental Chemistry, vol. 18, pp. 37-45, 2017.

[7] A. Boudebbouz, S. Boudalia, A. Bousbia, S. Habila, M. I. Boussadia, and Y. Gueroui, "Heavy metals levels in raw cow milk and health risk assessment across the globe: a systematic review," Science of The Total Environment, Article ID 141830, 2020.

[8] S. Hassani, F. Tavakoli, M. Amini, F. Kobarfard, A. NiliAhmadabadi, and O. Sabzevari, "Occurrence of melamine contamination in powder and liquid milk in market of Iran," Food Additives \& Contaminants: Part A, vol. 30, pp. 413-420, 2013.

[9] S. Sachi, J. Ferdous, M. H. Sikder, and S. A. K. Hussani, "Antibiotic residues in milk: past, present, and future," Journal of Advanced Veterinary and Animal Research, vol. 6, p. 315, 2019.

[10] X. Qu, C. Su, N. Zheng, S. Li, L. Meng, and J. Wang, "A survey of naturally-occurring steroid hormones in raw milk and the associated health risks in Tangshan City, Hebei Province, China," International Journal of Environmental Research and Public Health, vol. 15, p. 38, 2018.

[11] T. Snoj and G. Majdič, "Mechanisms in Endocrinology: estrogens in consumer milk: is there a risk to human reproductive health?" European journal of endocrinology, vol. 179, pp. R275-R286, 2018.

[12] P.-N. Jouan, Y. Pouliot, S. F. Gauthier, and J.-P. Laforest, "Hormones in bovine milk and milk products: a survey," International Dairy Journal, vol. 16, pp. 1408-1414, 2006.

[13] B. B. Hirpessa, B. H. Ulusoy, and C. Hecer, "Hormones and hormonal anabolics: residues in animal source food, potential public health impacts, and methods of analysis," Journal of Food Quality, vol. 2020, Article ID 5065386, 12 pages, 2020.

[14] H. Malekinejad, P. Scherpenisse, and A. A. Bergwerff, "Naturally occurring estrogens in processed milk and in raw milk (from gestated cows)," Journal of Agricultural and Food Chemistry, vol. 54, pp. 9785-9791, 2006.

[15] G. J. Khaniki, "Chemical contaminants in milk and public health concerns: a review," International Journal of Dairy Science, vol. 2, pp. 104-115, 2007.

[16] H. Malekinejad and A. Rezabakhsh, "Hormones in dairy foods and their impact on public health-a narrative review article," Iranian Journal of Public Health, vol. 44, p. 742, 2015.

[17] K. Maruyama, T. Oshima, and K. Ohyama, "Exposure to exogenous estrogen through intake of commercial milk produced from pregnant cows," Pediatrics International, vol. 52, pp. 33-38, 2010.

[18] D. Tat, S. A. Kenfield, J. E. Cowan et al., "Milk and other dairy foods in relation to prostate cancer recurrence: data from the cancer of the prostate strategic urologic research endeavor $\left(\mathrm{CaPSURE}^{\mathrm{TM}}\right)$," The Prostate, vol. 78, pp. 32-39, 2018.

[19] S. C. Larsson, N. Orsini, and A. Wolk, "Milk, milk products and lactose intake and ovarian cancer risk: a meta-analysis of epidemiological studies," International Journal of Cancer, vol. 118, pp. 431-441, 2006.

[20] D. Ganmaa, X. Cui, D. Feskanich, S. E. Hankinson, and W. C. Willett, "Milk, dairy intake and risk of endometrial cancer: a 26-year follow-up," International Journal of Cancer, vol. 130, pp. 2664-2671, 2012.

[21] Y. Yang, B. Shao, J. Zhang, Y. Wu, and H. Duan, "Determination of the residues of 50 anabolic hormones in muscle, milk and liver by very-high-pressure liquid chromatography-electrospray ionization tandem mass spectrometry," Journal of Chromatography, vol. B877, pp. 489-496, 2009. 
[22] S. Belouafa, F. Habti, S. Benhar et al., "Statistical tools and approaches to validate analytical methods: methodology and practical examples," International Journal of Metrology and Quality Engineering, vol. 9, 2017.

[23] L. J. Phillips and J. Moya, "Exposure factors resources: contrasting EPA's Exposure Factors Handbook with international sources," Journal of Exposure Science and Environmental Epidemiology, vol. 24, pp. 233-243, 2014.

[24] M. C. Lucy, "Stress, strain, and pregnancy outcome in postpartum cows," Animal Reproduction, vol. 16, pp. 455-464, 2019.

[25] L. E. Hernández-Castellano, J. E. Nally, J. Lindahl et al., "Dairy science and health in the tropics: challenges and opportunities for the next decades," Tropical Animal Health and Production, vol. 51, 2019.

[26] T. Sato, S. Miyagawa, and T. Iguchi, "Subchapter 94G-estradiol-17 $\beta$," in Handbook of Hormones, Y. Takei, H. Ando, and K. Tsutsui, Eds., Academic Press, San Diego, CA, USA, 2016.

[27] J. Tong, I. Thompson, X. Zhao, and P. Lacasse, "Effect of $17 \beta$ estradiol on milk production, hormone secretion, and mammary gland gene expression in dairy cows," Journal of Dairy Science, vol. 101, pp. 2588-2601, 2018.

[28] C. Mufudza, W. Sorofa, and E. T. Chiyaka, "Assessing the effects of estrogen on the dynamics of breast cancer," Computational and Mathematical Methods in Medicine, vol. 2012, Article ID 473572, 14 pages, 2012.

[29] C. Chen, X. Mi, Y. Yuan et al., "A preliminary risk assessment of potential exposure to naturally occurring estrogens from Beijing (China) market milk products," Food and Chemical Toxicology, vol. 71, pp. 74-80, 2014.

[30] D. W. Farlow, X. Xu, and T. D. Veenstra, "Quantitative measurement of endogenous estrogen metabolites, risk-factors for development of breast cancer, in commercial milk products by LC-MS/MS," Journal of Chromatography, vol. B877, pp. 1327-1334, 2009.

[31] I. Adriaens, W. Saeys, T. Huybrechts et al., "A novel system for on-farm fertility monitoring based on milk progesterone," Journal of Dairy Science, vol. 101, pp. 8369-8382, 2018.

[32] M. H. Lashari and Z. Tasawar, "The effect of PGF2 on persistent corpus luteum in Sahiwal cows," International Journal of Livestock Production, vol. 3, pp. 1-5, 2012.

[33] O. Ginther, L. Nuti, B. Wentworth, and W. Tyler, "Progesterone concentration in milk and blood during pregnancy in cows," Proceedings of The Society for Experimental Biology and Medicine, vol. 146, pp. 354-357, 1974.

[34] P. Regal, A. Cepeda, and C. Fente, "Development of an LCMS/MS method to quantify sex hormones in bovine milk and influence of pregnancy in their levels," Food Additives \& Contaminants: Part A, vol. A29, pp. 770-779, 2012.

[35] L. Wu, C. Xu, C. Xia et al., "Development and application of an ELISA kit for the detection of milk progesterone in dairy cows," Monoclonal Antibodies in Immunodiagnosis and Immunotherapy, vol. 33, pp. 330-333, 2014.

[36] J. Pennington, S. Spahr, and J. Lodge, "Influences on progesterone concentration in bovine milk," Journal of Dairy Science, pp. 259-266, 1981.

[37] M. Wiltbank, A. Souza, J. Giordano et al., "Positive and negative effects of progesterone during timed AI protocols in lactating dairy cattle," Animal Reproduction, vol. 9, pp. 231241, 2018.

[38] D. D. Baird, "The gestational timing of pregnancy loss: adaptive strategy?" American Journal of Human Biology: The
Official Journal of the Human Biology Association21, pp. 725-727, 2009.

[39] FAO/WHO, 2000, https://apps.who.int/food-additives-cont aminants-jecfa-database/chemical.aspx? chemID $=1835$. 